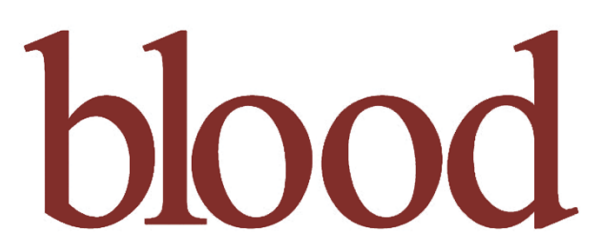

2006 107: 2936-2942

Prepublished online Dec 1, 2005;

doi:10.1182/blood-2005-06-2314

\title{
Human neutrophil peptides induce interleukin-8 production through the P2Y 6 signaling pathway
}

Aye Aye Khine, Lorenzo Del Sorbo, Rosanna Vaschetto, Stefanos Voglis, Elizabeth Tullis, Arthur S. Slutsky, Gregory P. Downey and Haibo Zhang

Updated information and services can be found at:

http://bloodjournal.hematologylibrary.org/cgi/content/full/107/7/2936

Articles on similar topics may be found in the following Blood collections:

Phagocytes (973 articles)

Signal Transduction (1930 articles)

Information about reproducing this article in parts or in its entirety may be found online at:

http://bloodjournal.hematologylibrary.org/misc/rights.dtl\#repub_requests

Information about ordering reprints may be found online at:

http://bloodjournal.hematologylibrary.org/misc/rights.dtl\#reprints

Information about subscriptions and ASH membership may be found online at:

http://bloodjournal.hematologylibrary.org/subscriptions/index.dtl

Blood (print ISSN 0006-4971, online ISSN 1528-0020), is published semimonthly by the American Society of Hematology, 1900 M St, NW, Suite 200, Washington DC 20036.

Copyright 2007 by The American Society of Hematology; all rights reserved.

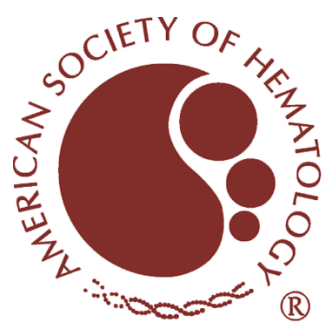




\title{
Human neutrophil peptides induce interleukin-8 production through the $\mathrm{P} 2 \mathrm{Y}_{6}$ signaling pathway
}

Aye Aye Khine, Lorenzo Del Sorbo, Rosanna Vaschetto, Stefanos Voglis, Elizabeth Tullis, Arthur S. Slutsky, Gregory P. Downey, and Haibo Zhang

\begin{abstract}
Antimicrobial human neutrophil peptides (HNPs) play a pivotal role in innate host defense against a broad spectrum of prokaryotic pathogens. In addition, HNPs modulate cellular immune responses by producing the chemokine interleukin-8 (IL-8) in myeloid and epithelial cells and by exerting chemotaxis to $\mathrm{T}$ cells, immature dendritic cells, and monocytes. However, the mechanisms by which HNPs
\end{abstract}

modulate the immune responses in the eukaryotic cells remain unclear. We demonstrated that, as with adenosine triphosphate (ATP) and uridine diphosphate (UDP), HNP stimulation of human lung epithelial cells selectively induced IL-8 production in 10 pro- and anti-inflammatory cytokines examined. HNP-induced IL-8 release was inhibited by treatment with the nucleotide receptor antagonists suramin and reactive blue. Transfection of lung epithelial cells with antisense oligonucleotides targeting specific purinergic $P 2 Y$ receptors revealed that the $\mathrm{P}_{2} \mathrm{Y}_{6}$ (ligand of UDP) signaling pathway plays a predominant role in mediating HNP-induced IL-8 production. (Blood. 2006;107:2936-2942)

(C) 2006 by The American Society of Hematology

\section{Introduction}

Among the antimicrobial compounds stored in the azurophilic granules, human neutrophil peptides (HNPs) are the most abundant, constituting up to $50 \%$ of the total protein content within human neutrophils. ${ }^{1,2}$ HNPs, also known as $\alpha$-defensins, are small cationic peptides with 6 characteristic, highly conserved cysteine residues and 3 intramolecular disulfide bonds. ${ }^{3-5}$ HNPs exhibit antimicrobial activity against a variety of microorganisms, such as Gram-positive and Gram-negative bacteria, viruses, and fungi, through charge-dependent pore formation.

Normal plasma levels of HNPs range from undetectable levels to 50 to $100 \mathrm{ng} / \mathrm{mL}$. In patients experiencing the onset of bacterial infection, those with nonbacterial infection, and those with pulmonary tuberculosis, mean HNP levels were 2- to 4-fold greater than they were in healthy volunteers. ${ }^{6}$ In patients with sepsis, HNP levels might be elevated to concentrations measured in milligrams per milliliter. ${ }^{3}$ In lung lavage fluid, HNP concentrations were 50 -fold higher in patients with ARDS than in healthy controls, ${ }^{7}$ 5 orders of magnitude greater in patients with bacterial pneumonia than in healthy volunteers, ${ }^{6}$ and 31 -fold higher in patients with diffuse panbronchiolitis than in controls. ${ }^{8}$ In sputum, we have shown an HNP concentration of $240 \pm 40 \mu \mathrm{g} / \mathrm{mL}$ in patients with cystic fibrosis compared with undetectable levels in healthy controls. ${ }^{9}$ These and other studies showing increased levels of HNP in the circulation and in the airways of patients with inflammatory lung diseases suggest that HNPs may contribute to the pathogenesis of inflammatory lung disorders. ${ }^{6-12}$

Indeed, in addition to their microbicidal role, extracellular HNPs can modulate immunologic responses. For example, HNPs are chemotactic to human $\mathrm{CD}^{+} / \mathrm{CD} 45 \mathrm{RA}^{+}$naive $\mathrm{T}$ cells, $\mathrm{CD}{ }^{+}$
T cells, immature human dendritic cells, ${ }^{13}$ and monocytes. ${ }^{14}$ Stimulation of human lung epithelial cells and primary bronchial epithelial cells with HNPs induces the production of interleukin-8 (IL-8) through the transcriptional regulation of IL-8 mRNA expression. ${ }^{15} \mathrm{IL}-8$ is a 6 - to $8-\mathrm{kDa}$ protein produced by a variety of cell types, including monocytes, lymphocytes, granulocytes, fibroblasts, epithelial cells, and endothelial cells. ${ }^{16} \mathrm{IL}-8$ is an inflammatory chemokine that functions as a neutrophil chemoattractant and activating factor. It also attracts eosinophils, basophils, and a subpopulation of lymphocytes. ${ }^{17}$

HNPs and certain chemokines share characteristics such as size, cationic charge, and disulfide bonding and biologic activities such as chemotaxis and antimicrobial properties. ${ }^{18,19}$ Although they lack amino acid sequence homology, the 3-dimensional structures of human $\beta$-defensins 1 and 2 and the CC chemokine CCL20 are similar, and all 3 molecules specifically interact with the CCL20 receptor CCR6 and induce similar biologic responses. ${ }^{20}$ However, HNP-dependent chemotaxis is not mediated by CCR6 ${ }^{13}$ and the mechanisms by which HNPs induce IL-8 production remain unknown.

Purinergic $\mathrm{P} 2$ receptors, including the $\mathrm{P} 2 \mathrm{X}$ and $\mathrm{P} 2 \mathrm{Y}$ families, are functional ligands of extracellular nucleotides that mediate intracellular signal transduction. $\mathrm{P} 2 \mathrm{X}$ receptors are a family of adenosine triphosphate (ATP)-activated cation channels $\left(\mathrm{P}_{2} \mathrm{X}_{1}\right.$ to $\mathrm{P} 2 \mathrm{X}_{7}$ ) that open in response to ATP binding. ${ }^{21}$ The P2Y family members are pertussis toxin-sensitive, $\mathrm{G}_{\mathrm{i}}$-protein-coupled receptors. At least 8 subtypes of $\mathrm{P} 2 \mathrm{Y}$ receptors $\left(\mathrm{P} 2 \mathrm{Y}_{1}, \mathrm{P}_{2} \mathrm{Y}_{2}, \mathrm{P} 2 \mathrm{Y}_{4}\right.$, $\mathrm{P}_{2} \mathrm{Y}_{6}, \mathrm{P} 2 \mathrm{Y}_{11}, \mathrm{P} 2 \mathrm{Y}_{12}, \mathrm{P} 2 \mathrm{Y}_{13}$, and $\mathrm{P} 2 \mathrm{Y}_{14}$ ) expressed by mammalian cells have been identified, and each has different nucleotidebinding affinity. ${ }^{22-24}$
From the Departments of Anaesthesia and Critical Care Medicine, St Michael's Hospital; and the Interdepartmental Division of Critical Care Medicine, Division of Respirology, Department of Physiology, University of Toronto, ON, Canada.

Submitted June 9, 2005; accepted November 20, 2005. Prepublished online as Blood First Edition Paper, December 1, 2005; DOI 10.1182/blood-2005-06-2314.

Supported by Canadian Institutes of Health Research (CIHR) grants MA-8558 (A.S.), MT-10994 (G.D.), and MOP-69042 (H.Z.) and by an Ontario Thoracic Society (OTS) Grant-in-Aid (H.Z.). A.A.K. is the recipient of a Canadian Lung
Association/GSK/CIHR Fellowship Award. H.Z. is the recipient of a ClHR New Investigator Award.

Reprints: Haibo Zhang, St Michael's Hospital, Rm 7-007, Queen Wing, 30 Bond St, Toronto, Ontario M5B 1W8, Canada; e-mail: haibo.zhang @utoronto.ca.

The publication costs of this article were defrayed in part by page charge payment. Therefore, and solely to indicate this fact, this article is hereby marked "advertisement" in accordance with 18 U.S.C. section 1734.

(C) 2006 by The American Society of Hematology 
Four isoforms of $\mathrm{P} 2 \mathrm{Y}$ receptors, including $\mathrm{P}_{2} \mathrm{Y}_{2}(\mathrm{ATP}=$ uridine triphosphate [UTP]), $\mathrm{P}_{4} \mathrm{Y}_{4}$ (UTP $>>$ ATP), $\mathrm{P}_{2} \mathrm{Y}_{6}$ (uridine diphosphate [UDP]), and $\mathrm{P}_{2} \mathrm{Y}_{14}$ (UDP glucose), are expressed in the lung. ${ }^{22,23} \mathrm{P} 2 \mathrm{Y}$ receptors mediate a wide range of cellular responses, including chemotaxis to $\mathrm{CD}^{+}{ }^{+} \mathrm{T}$ cells and induction of IL-8 expression by a variety of human epithelial and immune cells. ${ }^{25,26}$ Recent studies have demonstrated UDP (ligand of $\mathrm{P}_{2} \mathrm{Y}_{6}$ )dependent IL-8 production from THP-1 monocytes, ${ }^{27}$ human eosinophils, ${ }^{26}$ and human mature dendritic cells. ${ }^{28}$ In addition, products of ATP hydrolysis, such as adenosine monophosphate $(\mathrm{AMP})^{29,30}$ and adenosine ${ }^{31}$ by cell-surface-associated nucleotidases, can also mediate IL-8 induction (Figure 1).

In the present study, we tested the hypothesis that HNPs induce IL-8 production through purinergic receptor signaling in human lung epithelial cells. We demonstrate that HNPs selectively induce IL-8 production predominantly through a $\mathrm{P}_{2} \mathrm{Y}_{6}$ signaling pathway (Figure 1).

\section{Materials and methods}

\section{Source of HNPs}

HNPs were purified from patients with cystic fibrosis, as previously described..$^{32,33}$ To minimize variability from one patient to another, sputum was pooled from at least 20 patients with cystic fibrosis before purification. With respect to possible variability from one batch to another, at least 3 different batches of purified HNPs were used to stimulate cells in all experiments reported in the present study. HNPs were used as a mixture of HNP-1, HNP-2, and HNP-3 identified by $12.5 \%$ acid-urea polyacrylamide gel electrophoresis and by mass spectrometry (Mass Spectrometry Laboratory, Molecular Medicine Research Center, University of Toronto, Toronto, ON, Canada). ${ }^{32}$ Because the relative intensities of the HNP-1, HNP-2, and HNP-3 peaks are measured quantities, mass spectrometry allows an estimate of the content of the 3 components in the HNP mixture. Average percentage compositions calculated from 15 batches of the purified HNP mixture were $72.2 \%$ for HNP-1, 16.4\% for HNP-2, and 11.4\% for HNP-3. Purified HNPs were reconstituted in $0.01 \%$ acetic acid and were tested by bacterial killing and endotoxin detection assays before use. ${ }^{32,33}$ Synthetic HNP-1 (Sigma, St Louis, MO), followed by use of the purified HNPs, was used to conduct pilot experiments.

\section{Cell cultures}

Human small airway epithelial cells (SAECs; Cambrex, East Rutherford, $\mathrm{NJ})$ were cultured in the SAEC medium (Cambrex) at $37^{\circ} \mathrm{C}$ in a $5 \%$ $\mathrm{CO}_{2}$-humidified incubator. A549 human alveolar epithelial type 2-like cells (ATCC, Rockville, MD) were maintained as monolayers in DMEM with L-glutamine (Gibco, Grand Island, NY) supplemented with $50 \mu \mathrm{g} / \mathrm{mL}$

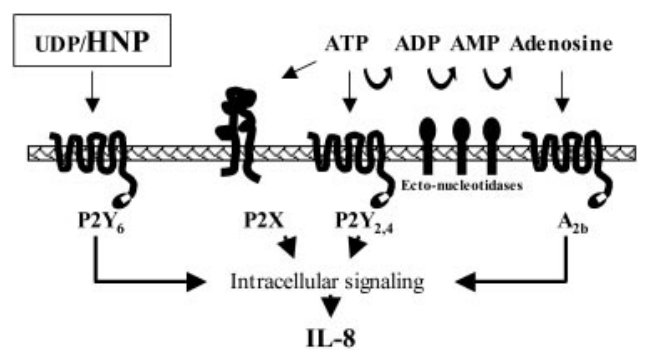

Figure 1. Alternative pathways of nucleotide/nucleoside receptor-mediated IL-8 induction. UDP/HNP induces IL-8 production through the 7-transmembrane, G-protein-coupled receptor P2Y $\mathrm{Y}_{6}$, whereas ATP-dependent IL-8 production is mediated by $P 2 Y_{2}$ and $P 2 Y_{4}$ and by $P 2 X$ ligand-gated ion channel. Extracellularly released ATP is hydrolyzed to ADP, AMP, and nucleoside adenosine by cell-surfaceassociated ecto-nucleotidases. Adenosine also induces IL- 8 production by $A_{2 b}$ receptor. $^{21}$ gentamicin (Gibco) and 10\% heat-inactivated fetal bovine serum (complete medium; Gibco). ${ }^{34}$

\section{Transfection of antisense oligonucleotides}

Transfection of SAECs and A549 cells with the sense or antisense oligonucleotides (final concentration, $2.5 \mu \mathrm{M}$ ) corresponding to the translation initiation sites of human $\mathrm{P}_{2} \mathrm{Y}_{2}, \mathrm{P}_{2} \mathrm{Y}_{4}$, and $\mathrm{P} 2 \mathrm{Y}_{6}$ were performed with the use of Lipofectamine reagent (Gibco). Sequences included $\mathrm{P} 2 \mathrm{Y}_{2}$ sense, 5'-GCGATGGCAGCAGACCTGG-3'; P2 $Y_{2}$ antisense, 5'-CCAGGTCTGCTGCCAT-CGC-3'; P2Y 4 sense, 5'-GCCATGGCCAGTACAGAGT-3'; $\mathrm{P}^{2} \mathrm{Y}_{4}$ antisense, 5'-ACTCTGT-ACTGGCCATGC-3'; P2Y 6 sense, 5' GCCATGGAATGGGACAATG-3'; and P2Y 6 antisense, 5'-CATTGTCCCATTCCATGGC- $3^{\prime}$. The transfection medium was replaced with complete DMEM 4 hours after transfection, and the cells were incubated overnight at $37^{\circ} \mathrm{C}$. Cells were washed with phosphate-buffered saline (PBS) and serum-free medium before stimulation with HNPs.

\section{Reverse transcriptase-polymerase chain reaction assay}

Total RNA was extracted from A549 cells grown in a 6-well plate using Trizol reagent (Invitrogen, Life Technologies, Carlsbad, CA). First-strand cDNA was prepared by using the SuperScript first-strand synthesis system (Invitrogen), and reverse transcriptase-polymerase chain reaction (RTPCR) was performed in a GeneAmp PCR apparatus (Amersham Pharmacia Biotech, Piscataway, NJ) with Platinum PCR supermix (Invitrogen). The following primers were used to amplify the conserved regions in the third and seventh transmembrane domains of $\mathrm{P} 2 \mathrm{Y}$ receptors ${ }^{35}: \mathrm{P}_{2} \mathrm{Y}_{2}$ sense primer, 5' -CCAGGCCCCCGTGC TCTACTTTG-3'; P2Y $_{2}$ antisense primer, 5'-CATGTTGATGGCGTTGAGGGTGTG-3' (367 bp); P2Y 4 sense primer, 5'-CGTCTTCTCGCCTCCGCTCTCT-3'; ${ }^{\prime} 2 \mathrm{Y}_{4}$ antisense primer, 5'

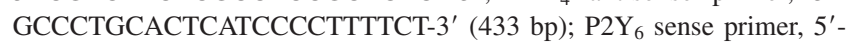
CCGCTGAACATCTGTGTC-3'; P2 ${ }_{6}$ antisense primer, 5' -AGAGCCATGCCATAGGGC-3' (464 bp); housekeeping gene GADPH sense primer, 5'-CTACTGGCGCTGCCAAGGCTGT-3'; and GADPH antisense primer, 5'-GCCATGAGGTCCACCACCCTGT-3' (358 bp). PCR was performed by denaturation at $94^{\circ} \mathrm{C}$ for 5 minutes followed by 35 cycles of amplification $\left(94^{\circ} \mathrm{C}\right.$ for 30 seconds, $58^{\circ} \mathrm{C}$ for 30 seconds, $72^{\circ} \mathrm{C}$ for 50 seconds), and extension at $72{ }^{\circ} \mathrm{C}$ for 7 minutes. ${ }^{35} \mathrm{PCR}$ products were resolved on a $1.5 \%$ agarose gel.

\section{SDS-polyacrylamide gel electrophoresis and Western blotting}

A549 cells were detached with cell scrapers in cold cell-lysis buffer $(50 \mathrm{mM}$ HEPES pH 7.4, $150 \mathrm{mM} \mathrm{NaCl}, 5 \mathrm{mM}$ EDTA, $1 \mathrm{mM}$ DTT, 0.05\% Triton $\mathrm{X}-100,100 \mu \mathrm{g} / \mathrm{mL}$ PMSF, and 1:1000 protease inhibitor cocktail [Sigma, St Louis, MO]) and were lysed by passage through a 21 -gauge needle 10 times. The cell lysate was incubated for 1 hour at $4^{\circ} \mathrm{C}$ and centrifuged at $10000 \mathrm{~g}$ for 10 minutes at $4^{\circ} \mathrm{C}$. The protein concentration of the total cell lysate (supernatant) was measured using a Bio-Rad protein assay (Bio-Rad, Mississauga, ON, Canada). Cell lysates ( $5 \mu \mathrm{g}$ each) were resolved on $12 \%$ SDS-PAGE using a Mini-Protean 3 Electrophoresis Cell (Bio-Rad) at 150 $\mathrm{V}, 400 \mathrm{mAmp}$ for 1 hour and were transferred to nitrocellulose membrane using a semidry system (Bio-Rad). The membrane was washed twice in $\mathrm{dH}_{2} \mathrm{O}$ and was blocked with PBS containing $0.1 \%$ Tween-20 and $0.5 \%$ nonfat dry milk before overnight incubation with $1 \mu \mathrm{g} / \mathrm{mL}$ polyclonal rabbit anti-human $\mathrm{P}_{2} \mathrm{Y}_{6}$ primary antibody (Affinity BioReagents, Golden, $\mathrm{CO}$ ) in blocking buffer at $4^{\circ} \mathrm{C}$, followed by 1:5000 goat anti-rabbit IgG-HRP secondary antibody (Jackson ImmunoResearch Laboratories, West Grove, PA) in blocking buffer for 1 hour at room temperature. The membrane was washed before peroxidase substrate TMB $\left(3,3^{\prime}, 5,5^{\prime}\right.$ tetramethylbenzidine; Sigma) was added. Anti-human $\beta$-actin antibody 2 monoclonal antibody (Alpha Diagnostic International, San Antonio, TX) was used as a loading control for Western blots.

\section{Lactate dehydrogenase cytotoxicity detection}

LDH is a stable cytoplasmic enzyme present in most cells and is released into cell-culture supernatant when the cell membrane is damaged. To select the optimal dose of the blocking reagents used, cytotoxicity was evaluated. SAEC or A549 cells seeded in 24-well plates were treated for 30 minutes at 
$37^{\circ} \mathrm{C}$ with different concentrations of blocking reagents, including sense and antisense oligonucleotides and nonspecific inhibitors (suramin and reactive blue) of $\mathrm{P} 2 \mathrm{Y}$ receptors, followed by incubation for 8 hours with HNP stimulation. Supernatants were then collected, and cells were washed with PBS. Serum-free DMEM $(200 \mu \mathrm{L})$ was added, and A549 cells were lysed by freeze-thaw cycles (frozen at $-80^{\circ} \mathrm{C}$ for 30 minutes and thawed at $37^{\circ} \mathrm{C}$ ). Supernatants were pooled and centrifuged at $250 \mathrm{~g}$ for 5 minutes. LDH concentrations in cell-culture supernatants and cell lysates were measured using a Cytotoxicity Detection (LDH) Kit (Roche Applied Science, Penzberg, Germany).

\section{LiquiChip multiple cytokine assay}

Cell culture supernatants from indicated experiments were collected for simultaneous measurement of multiple cytokines (IL-1 $\beta$, IL-2, IL-4, IL-6, IL-8, IL-10, IL-12, TNF- $\alpha$, IFN- $\gamma$, and GM-CSF) using the LiquiChip Human 10-cytokine kit (Qiagen, Valencia, CA).

\section{IL-8 enzyme-linked immunosorbent assay}

To confirm the specificity of IL-8 production after HNP stimulation, IL-8 levels were also measured from cell-culture supernatants by using a human IL-8 ELISA kit (Biosource International, Camarillo, CA). Correlation was excellent $(r=0.93 ; P<.05)$ in IL-8 concentrations measured between the LiquiChip cytokine assay and the ELISA kit.

\section{I-HNP binding to lung A549 cells}

To demonstrate the binding of HNPs on the A549 cell surface, HNPs were labeled with sodium iodine I 125 (125I) using IODO bead iodination reagent (Pierce Biotechnology, Rockford, IL) according to the manufacturer's instruction. ${ }^{125} \mathrm{I}-\mathrm{HNP}$, at a final concentration ranging from 0 to $0.8 \mu \mathrm{M}$, was added to A549 cells in DMEM for total binding. To determine specific ${ }^{125}$ I-HNP binding, a parallel assay was carried out in A549 cells by 30-minute pretreatment with a 40-fold excess concentration of unlabeled HNPs before addition of the ${ }^{125}$ I-HNP dilutions. Cells were then incubated on ice with ${ }^{125} \mathrm{I}$-HNP for another 30 minutes, washed, and dissolved in $\mathrm{NaOH}$ before radioactive counting (Auto-Gamma 5650; Packard Instruments, Downers Grove, IL).

\section{Competitive binding of HNP with nucleotides on cell-surface P2Y receptors (cell ELISA)}

A549 cells $\left(5 \times 10^{4} /\right.$ well $)$ seeded overnight in 96 -well plates were washed in PBS, and $50 \mu \mathrm{L}$ serum-free DMEM was added. To perform binding assays at an equimolar ratio, molar concentrations of HNP and a 40-fold excess molar concentration of the competitors (ATP and UDP) were calculated (ie, $10 \mu \mathrm{g} / \mathrm{mL}$ HNP is equal to $2.8 \mu \mathrm{M}$; UDP or ATP concentration was calculated by $2.8 \times 40 \mu \mathrm{M}$ multiplied by the molecular weight of UDP or ATP and then converted to a corresponding concentration [in $\mu \mathrm{g} / \mathrm{mL}$ ] for stock preparation, respectively). Because the composition of the HNP mixture was known after purification of the sputum from patients with cystic fibrosis and HNP-1 (MWt 3442) is a more abundant isoform than HNP-2 (MWt 3371) and HNP-3 (MWt 3486), we used the molecular mass of HNP-1, which is close to the mean value of the molecular masses of HNP-1, HNP-2, and HNP-3, to estimate the molar concentration of the HNP mixture. Cells were then incubated with serial dilutions of HNP $(0-0.3 \mu \mathrm{M})$ at room temperature for 30 minutes, with or without pretreatment with serial dilutions of ATP or UDP $(0-100 \mu \mathrm{M})(40 \mathrm{M}$ excess of HNP concentrations) at room temperature for 30 minutes. After they were washed with PBS, the cells were fixed with $4 \%$ paraformaldehyde in PBS for 15 minutes, followed by blocking with $0.5 \%$ Tween- 20 and $0.5 \%$ milk in PBS for 30 minutes. HNP binding to the cell surface was measured by using rabbit polyclonal anti-HNP antibody $(10 \mathrm{ng} / \mathrm{mL}$; Host Defense Research Center, Toronto, ON, Canada), HRP-conjugated goat anti-rabbit antibody (1:4000 dilution) (Jackson ImmunoResearch), and TMB substrate (Sigma) with thorough washing at every step. The reaction was stopped by the addition of $1 \mathrm{M}$ sulfuric acid. The absorbance of each well was measured by a microtiter plate reader at $450 \mathrm{~nm}$.

\section{Statistical analysis}

Data are expressed as mean \pm SEM. Two-way ANOVA, followed by the Turkey/Kramer test, was used for statistical analysis. Differences were considered statistically significant at $P$ values less than .05 .

\section{Results}

\section{HNP selective induction of IL-8 in lung epithelial cells}

Stimulation of A549 cells with various concentrations of HNP resulted in the induction of IL- 8 in the 10 cytokines assayed (Figure 2A). HNP-induced IL-8 production was dose dependent, ranging from $33 \pm 6 \mathrm{pg} / \mathrm{mL}$ in control to $1201 \pm 79 \mathrm{pg} / \mathrm{mL}$ at $100 \mu \mathrm{g} / \mathrm{mL}$ HNP, the highest concentration tested. Importantly, HNP-induced IL-8 release was apparent at doses as low as $3 \mu \mathrm{g} / \mathrm{mL}$.

To examine whether the selective induction of IL- 8 was caused by deficient production of other cytokines by A549 cells, recombinant human TNF- $\alpha$ at 0 to $50 \mathrm{ng} / \mathrm{mL}$ was used to challenge the cells because TNF- $\alpha$ is a known stimulus to induce multiple cytokines in A549 cells. ${ }^{38}$ Stimulation of A549 cells with TNF- $\alpha$ induced the dose-dependent production of IL-1 $\beta$, IL-2, IL-6, and interferon- $\gamma$ in addition to IL-8 (Figure 2B). Although the TNF- $\alpha$ level increased dramatically (data not shown), it was unclear whether the increase was associated with autocrine stimulation or with another mechanism.

\section{ATP- and UDP-selective induction of IL-8 in lung epithelial cells}

As discussed, we observed that HNPs selectively induced IL-8 production in 10 pro- and anti-inflammatory cytokines examined. Several nucleotides induced similar patterns of IL- 8 response in a variety of cell types through different intracellular signaling pathways. To examine whether HNPs induced IL-8 production through nucleotide signaling pathways, A549 cells were incubated

A
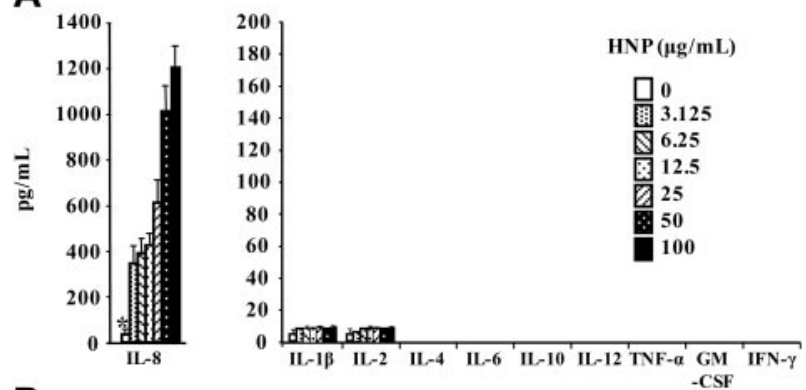

B
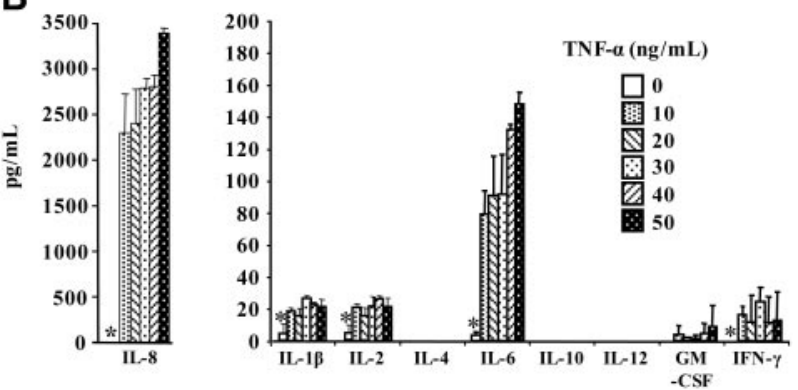

Figure 2. Cytokine profile of A549 cells in response to HNP and TNF- $\alpha$. A549 cells $\left(2.5 \times 10^{5}\right.$ cells/well in 24-well plate) were incubated in serum-free DMEM containing indicated concentrations of $\operatorname{HNP}(\mathrm{A})$ and recombinant human TNF- $\alpha$ (B) for 8 hours. Multiple cytokines in culture supernatants were simultaneously measured $(n=3)$. Concentrations of HNP and TNF- $\alpha$ were progressively increased, as indicated in the bar graphs. ${ }^{\star} P<.05$; control $(0)$ compared with HNP or TNF- $\alpha$ at all concentrations, respectively. 
Figure 3. Selective induction of IL-8 by ATP and UDP in A549 cells. (A) A549 cells were incubated for 8 hours in serum-free DMEM containing indicated concentrations of ATP, ADP, UTP, and UDP, and IL-8 levels in cell-culture supernatants were measured with the use of enzyme-linked immunosorbent assay (ELISA). (B) Because only ATP and UDP induce significant IL-8 production, multiple cytokines were measured in the cells stimulated with indicated concentrations of ATP and UDP for 8 hours $(n=3)$. ATP and UDP concentrations were progressively increased, as indicated in the bar graphs. ${ }^{*} P<.05$; control $(0)$ compared with ATP or UDP at all concentrations, respectively.
A

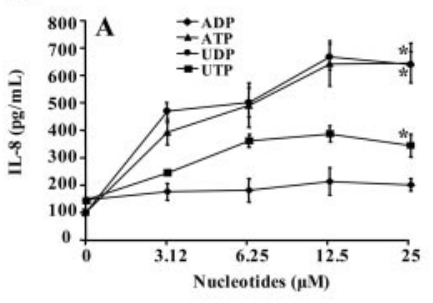

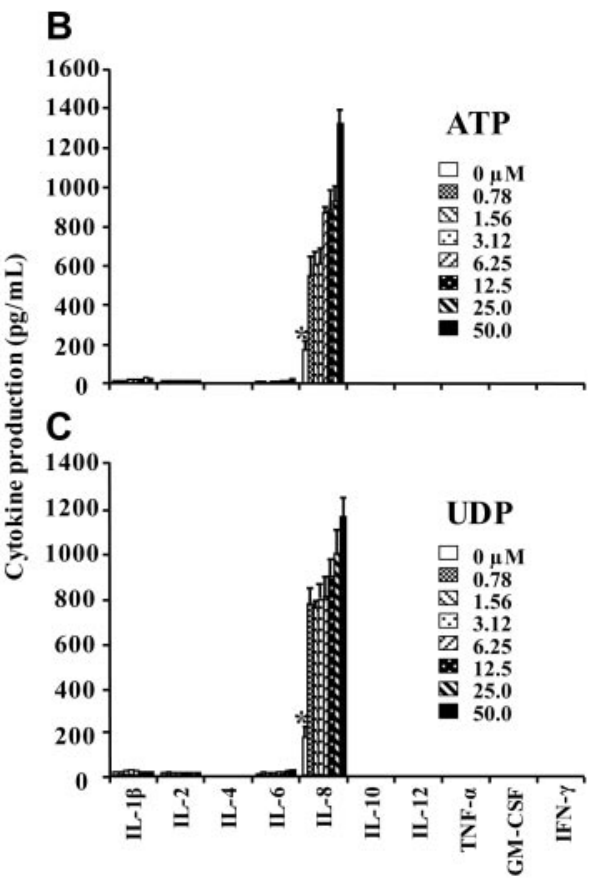

for 8 hours in the presence and absence of the nucleotides ATP, adenosine diphosphate (ADP), UTP, and UDP (3.12-25 $\mu \mathrm{M})$. IL-8 concentrations in the cell-culture supernatants were then determined. Figure 3A shows that ATP and UDP induced the dosedependent production of IL-8 from a concentration as low as $3.12 \mu \mathrm{M}$. UTP tended to increase, but ADP had no effect on IL-8 production. UTP is degraded into UDP, which may contribute to IL-8 production.

We further focused on cytokine profiles of the cells in response to a broad range of ATP and UDP concentrations. As with HNP stimulation, ATP and UDP selectively induced IL-8 production in 10 cytokines tested (Figure 3B-C). These observations suggest that HNP and nucleotides may share common cellular signaling pathways in mediating IL-8 production.

\section{Nucleotides mediate HNP-induced IL-8 production from lung epithelial cells}

Given that nucleotides are ligands for P2Y receptors, we examined whether blocking $\mathrm{P} 2 \mathrm{Y}$ receptors would result in the attenuation of HNP-induced IL-8 production. When A549 cells were pretreated with the nonspecific $\mathrm{P} 2 \mathrm{Y}$ receptor antagonists suramin and reactive blue at $100 \mu \mathrm{M}$, HNP-induced IL-8 production was blunted (Figure 4A). This inhibitory effect was not caused by cytotoxicity, as assessed by cell viability and LDH release (data not shown).

We theorized 2 mechanisms by which HNPs induce IL-8 production: (1) HNPs act directly on cell-surface nucleotide receptors; (2) HNPs act on cells through unknown mechanisms, resulting in the release of nucleotides that induce IL- 8 production through nucleotide receptors.

To examine whether HNPs can directly bind to surface nucleotide receptors, competitive HNP binding on the A549 cell surface was assessed by the addition of ${ }^{125} \mathrm{I}-\mathrm{HNP}$. Figure 4B illustrates that HNPs bound to the cell surface, but this binding was not blocked by ATP or UDP (Figure 4C), suggesting that HNPs do not bind directly to surface $\mathrm{P} 2 \mathrm{Y}$ receptors or, at least, that they do not share binding sites with the nucleotides.

We measured extracellularly released ATP and found no significant increase after HNP stimulation (data not shown). Other nucleotides were not measured because of the lack of reliable assays. Nucleotides can be readily degraded or can undergo interconversion by cell-surface-associated enzymes. Thus, we focused on examining the role of nucleotide signaling by inhibiting the expression of nucleotide receptors rather than indirectly measuring extracellularly released nucleotides.

\section{ATP-dependent signaling plays a minor role in HNP-induced IL-8 production}

Although HNPs did not induce ATP release, it remained unknown whether HNP-induced IL- 8 release is mediated by ATP signaling

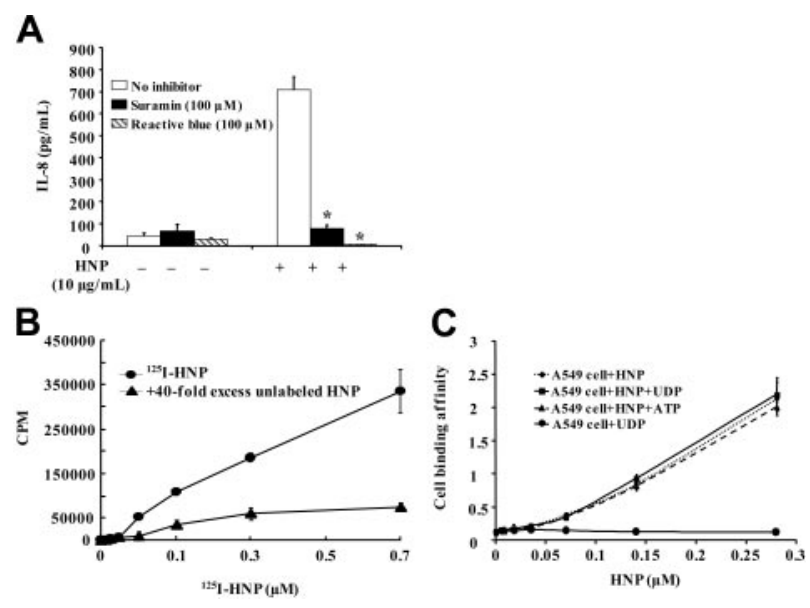

Figure 4. Effects of $\mathrm{P} 2 \mathrm{Y}$ receptor antagonists suramin and reactive blue HNP-induced IL-8 production, and HNP binding on A549 cells. (A) A549 cells $\left(2.5 \times 10^{5}\right.$ cells/well in 6-well plate) were incubated in serum-free DMEM containing $100 \mu \mathrm{M}$ suramin or reactive blue for 30 minutes, followed by the addition of $10 \mu \mathrm{g} / \mathrm{mL}$ HNP for 8 hours. IL-8 levels in supernatants were measured. ${ }^{*} P<.05$ suramin or reactive blue compared with no inhibitor, respectively. (B) A549 cells $\left(5 \times 10^{4}\right.$ cell/well in 96-well plate) were incubated in serum-free DMEM containing 0 to $0.7 \mu \mathrm{M}$ 125I-labeled HNP for 30 minutes on ice, with or without pretreatment with 40 -fold molar excess concentration of unlabeled HNP for 30 minutes. Cell-associated HNP binding was measured by radioactivity counting. CPM indicates counts per minute. (C) HNPs do not compete with ATP or UDP in engaging cell-surface binding sites. A549 cells were incubated in serum-free DMEM containing 0 to $2.8 \mu \mathrm{M}$ HNP for 30 minutes, with or without pretreatment with 0 to $100 \mu \mathrm{M}$ ATP or UDP for 30 minutes. A control group of cells incubated with UDP in the absence of HNP was included. Cell-surface HNP binding was measured by HNP-cell ELISA $(n=3)$. 
pathways including $\mathrm{P}_{2} \mathrm{Y}_{2}(\mathrm{ATP}=\mathrm{UTP})$ and $\mathrm{P} 2 \mathrm{Y}_{4}(\mathrm{UTP}>>$ ATP $)$ receptors, $\mathrm{P} 2 \mathrm{X}$ ligand-gated ion channels, ${ }^{26}$ and adenosine resulting from ATP degradation by nucleotidases through $\mathrm{A}_{2 \mathrm{~b}}$ receptor $^{30,31}$ (Figure 1). Involvement of these pathways was investigated with the use of specific blockers.

Given that no inhibitors or antibodies are available against specific $\mathrm{P} 2 \mathrm{Y}$ receptor phenotypes, antisense oligonucleotides targeting translation initiation sites of $\mathrm{P} 2 \mathrm{Y}$ mRNA were used to examine the roles of $\mathrm{P} 2 \mathrm{Y}_{2}$ and $\mathrm{P}_{2} \mathrm{Y}_{4}$ receptors in mediating HNP-induced IL-8 production. Figure 5A shows that resting A549 cells constitutively expressed $\mathrm{P} 2 \mathrm{Y}_{4}$ mRNA but not $\mathrm{P} 2 \mathrm{Y}_{2}$ mRNA. Treatment of the cells with $\mathrm{P} 2 \mathrm{Y}_{2}$ and $\mathrm{P} 2 \mathrm{Y}_{4}$ antisense oligonucleotides did not attenuate HNP-induced IL-8 production (Figure 5B).

We next examined the roles of $\mathrm{P} 2 \mathrm{X}$ receptor and adenosine $\left(\mathrm{A}_{2 \mathrm{~b}}\right)$ receptor in HNP-induced IL-8 induction by using specific antagonists. Although PPADS, a P2X receptor inhibitor, and alloxazine, an inhibitor of adenosine $\mathrm{A}_{2 \mathrm{~b}}$ receptor, decreased HNP-induced IL-8 production compared with nontreated cells, the differences did not reach statistical significance, indicating a minor role of P2X and adenosine receptors in mediating HNP-induced IL-8 production (Figure 5C).

\section{$\mathrm{P}^{2} \mathrm{Y}_{6}$ signaling regulates HNP-induced IL-8 production}

No reliable, sensitive assay is available to measure the extracellular concentration of UDP (the ligand of $\mathrm{P}_{2} \mathrm{Y}_{6}$ ). The role of the UDP-P2 $\mathrm{Y}_{6}$ signaling pathway in mediating HNP-induced IL-8 production was examined using $\mathrm{P}_{2} \mathrm{Y}_{6}$ antisense oligonucleotides. A549 cells constitutively express high levels of $\mathrm{P}^{2} \mathrm{Y}_{6}$ mRNA (Figure 6A). The use of $\mathrm{P}_{2} \mathrm{Y}_{6}$ antisense oligonucleotides blunted the expression of $\mathrm{P}_{2} \mathrm{Y}_{6}$ at mRNA (Figure $6 \mathrm{~A}$ ) and protein (Figure 6B) levels. Treatment of cells with $\mathrm{P}_{2} \mathrm{Y}_{6}$ antisense oligonucleotides resulted in approximately $60 \%$ reduction in HNP-induced IL-8 production compared with control $(P<.05)$ (Figure 6C). Similarly, when the experiments were repeated in primary human small airway epithelial cells, the use of $\mathrm{P}_{2} \mathrm{Y}_{6}$ antisense oligonucleotide attenuated HNP-induced IL-8 release by approximately $70 \%$ compared with control $(P<.05$; Figure 6D).

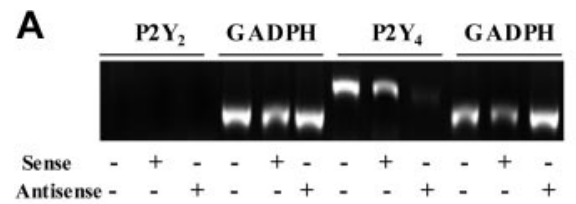

B

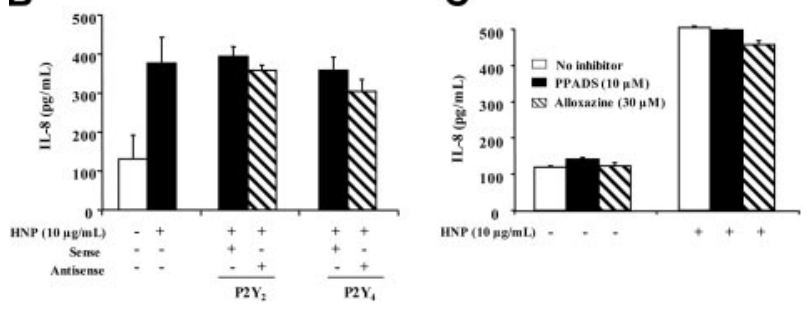

Figure 5. Role of $\mathrm{P} 2 \mathrm{X}, \mathrm{P} 2 \mathrm{Y}_{2}, \mathrm{P}_{2} \mathrm{Y}_{4}$, and $\mathrm{A}_{2 \mathrm{~b}}$ receptors in HNP-induced IL-8 production. (A) A549 cells were incubated in serum-free DMEM and lipofectamine reagent preparation containing $2.5 \mu \mathrm{M} \mathrm{P} 2 \mathrm{Y}_{2}$ and $\mathrm{P}_{2} \mathrm{Y}_{4}$ sense or antisense oligonucleotides, respectively, for 4 hours. RT-PCR of $\mathrm{P}_{2} \mathrm{Y}_{2}$ mRNA and $\mathrm{P}_{2} \mathrm{Y}_{4}$ mRNA analysis was performed. (B) Cells were incubated in serum-free DMEM and transfected with $\mathrm{P}_{2} \mathrm{Y}_{2}$ and $\mathrm{P}_{2} \mathrm{Y}_{4}$ sense or antisense oligonucleotides for 4 hours, washed with complete DMEM, and incubated overnight. After washing with PBS and incubation in serum-free DMEM containing $10 \mu \mathrm{g} / \mathrm{mL}$ HNP for 8 hours and IL-8, concentration was measured in supernatants $(n=3)$. (C) Cells were incubated in serum-free DMEM containing a final concentration of $10 \mu \mathrm{M}$ PPADS or $30 \mu \mathrm{M}$ alloxazine for 30 minutes, followed by the addition of $10 \mu \mathrm{g} / \mathrm{mL}$ HNP for 8 hours. IL-8 levels were measured in cell-culture supernatants $(n=3)$.
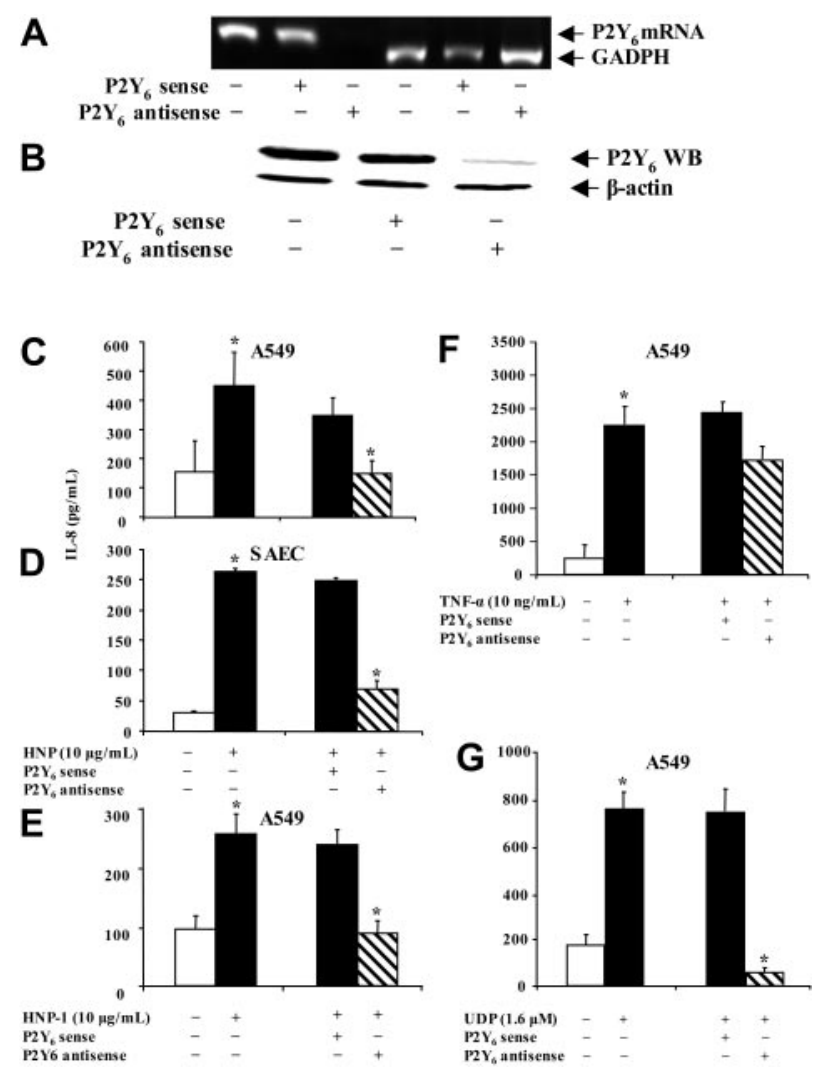

Figure 6. $\mathrm{P} 2 \mathrm{Y}_{6}$ mediates HNP-induced IL-8 production in human lung epithelial cells. A549 cells grown in complete DMEM were transfected with $2.5 \mu \mathrm{M} \mathrm{P} 2 \mathrm{Y}_{6}$ sense or antisense oligonucleotides for 4 hours. After washing, cells were incubated in complete medium overnight. (A) Total RNA was extracted, and RT-PCR of P2Y6 mRNA was performed. (B) Total $\mathrm{P}_{2} \mathrm{Y}_{6}$ protein level was determined from cell lysates by Western blotting (WB). After transfection with the oligonucleotides overnight, A549 cells (C) or SAEC cells (D) were incubated in serum-free DMEM containing the purified HNP for 8 hours. Three control groups were included to test the specificity of the antisense oligonucleotides on IL-8 release after stimulation with commercial synthetic HNP-1 (E), TNF- $\alpha(F)$, or UDP (G) in A549 cells. IL-8 levels in cell-culture supernatants were measured $(\mathrm{n}=3)$. ${ }^{\star} P<.05$; sense compared with antisense.

To confirm the results obtained by using the HNP mixture purified from patients with cystic fibrosis, experiments were repeated using commercially available synthetic HNP-1 and A549 cells because HNP-1 is the most abundant isoform among HNPs that include HNP-1, HNP-2, and HNP-3 in granule content in neutrophils ${ }^{36,37,39,40}$ and in the purified HNP mixture used. A similar inhibition of the HNP-1-induced IL-8 production was reproduced by the use of $\mathrm{P}_{2} \mathrm{Y}_{6}$ antisense oligonucleotide, but the cells showed much less IL-8 release in response to the commercially synthesized HNP-1 than to the purified HNP mixture (Figure 6E). These results indicate that HNP-1 stimulated the cells to produce IL-8, but the potency of the commercial HNP-1 was low. This may be explained by several factors: (1) the synthesized form contained molecular components that were not HNP-1; (2) proper folding was not achieved; and (3) the stimulating activity of individual peptide (ie, HNP-1) was low compared with the results using combined HNPs.

To further test the specificity of the blocking effect of $\mathrm{P}_{2} \mathrm{Y}_{6}$ antisense nucleotides on HNP-stimulated IL-8 release, A549 cells were stimulated with TNF- $\alpha$ and UDP, respectively, in the presence and absence of the $\mathrm{P}_{2} \mathrm{Y}_{6}$ antisense nucleotides for 8 hours. TNF- $\alpha$-induced IL- 8 release was not affected, but UDP-induced IL-8 release was completely blunted by the antisense nucleotide (Figure 6F-G), suggesting that HNP-induced IL-8 release may occur through the UDP pathway, distinct from the TNF- $\alpha$ signaling pathway. 


\section{Discussion}

The main findings of the present study are that HNPs selectively induced IL- 8 production in 10 common pro- and anti-inflammatory cytokines examined. NP-induced IL-8 production is dominantly regulated through the $\mathrm{P}_{2} \mathrm{Y}_{6}$ signaling pathway in the otherwise quiescent, nonprimed lung epithelial cells.

Neutrophils release large amounts of protein into the extracellular milieu as a consequence of degranulation, leakage during phagosome formation, and cell death and lysis. High concentrations of HNP associated with increased levels of IL- 8 have been reported in the lung lavage fluid, sputum, and plasma of patients with a variety of inflammatory lung diseases. ${ }^{6,7,41}$ We have demonstrated that HNPs at clinically relevant concentrations seen in the lung diseases can initiate inflammation by producing IL-8 and neutrophil migration, resulting in acute lung injury in vivo in mice. ${ }^{33}$ Because HNPs are not direct chemoattractants for neutrophils, neutrophil infiltration is largely dependent on the release of IL- 8 by lung epithelial cells in response to HNP stimulation. ${ }^{42,43}$ Thus, an understanding of the mechanisms by which HNPs induce IL-8 production would provide potential therapeutic approaches to control inflammatory courses.

We demonstrated selective induction of IL- 8 production in 10 cytokines tested by HNPs in resting epithelial cells. By comparison, at a given time, the same cells stimulated with TNF- $\alpha$ or LPS were able to release multiple cytokines, including IL- $1 \beta$, IL- 6 , and TNF- $\alpha$. A recent study reported that though HNPs induced the up-regulation of IL- $1 \beta$ and IL- 8 at gene levels, only IL- 8 production was increased at the protein level in primary human bronchial epithelial cells. ${ }^{43}$ Our findings are in agreement with other studies reporting that HNPs can induce multiple cytokines in the presence of a costimulus. When human monocytes were concurrently activated with Staphylococcus aureus or PMA, HNPs induced TNF- $\alpha$ and IL- $1 \beta$ expression. ${ }^{44}$ In subcultures in which A549 cells were preincubated overnight with dexamethasone and subsequently were stimulated for 6 hours with HNPs, van Wetering et $\mathrm{al}^{15}$ reported increased levels of IL- 8 and epithelial neutrophil activating peptide 78 (ENA-78). When CD3e-activated splenic and Peyer patch T cells isolated from mice were incubated with HNPs, an enhanced secretion of $\mathrm{T}_{\mathrm{H}} 1$ and $\mathrm{T}_{\mathrm{H}} 2$ cytokines was observed. ${ }^{37}$ Taken together, these data suggest that HNPs selectively induce IL-8 production through specific mechanisms in resting eukaryotic cells.

As with HNPs, lung epithelial-cell stimulation with ATP and UDP selectively induced IL-8 production, suggesting a linkage between HNPs and nucleotides in the sharing of common signaling pathways. UDP alone has been shown to induce IL- 8 release in the THP-1 monocytic cell line and human mature dendritic cells, ${ }^{27,28}$ whereas ATP and UDP stimulate human eosinophils to produce IL-8. ${ }^{26}$ In light of the direct stimulatory role of nucleotides to selectively induce IL-8 in different cell types ${ }^{26,27}$ and the similar effects of HNPs and nucleotides, we demonstrated that the use of the $\mathrm{P} 2$ receptor antagonists suramin and reactive blue almost completely blocked HNP-induced IL- 8 production. However, there appeared to be no direct interaction between HNP and $\mathrm{P} 2$ receptors because ATP and UDP did not compete with HNPs on cell-surface binding, or at least HNPs did not appear to share the same binding sites with ATP and UDP.

To further investigate the specific pathways involved in HNPmediated IL- 8 production, we focused on identifying the specific types of nucleotide receptors rather than the specific nucleotides involved, and we did so for several reasons. First, nucleotides are rapidly released in response to stimuli, and their autocrine functions are rapidly regulated by cell-surface-associated extracellular nucleotidases. ${ }^{29,45}$ Second, cell-surface-associated nucleoside diphosphokinase enzymes can rapidly convert the adenine nucleotides into uracil nucleotides, or vice versa. Third, nucleotides and their hydrolyzed products, nucleosides, exert biologic activities through a large family of receptors that display overlapping sensitivity to different agonists. ${ }^{22}$ Measurement of the nucleotide concentrations thus may not provide an accurate explanation to identify the specific pathways.

Several nucleotide receptor signaling pathways can be involved in IL-8 production in response to HNPs. ATP induces IL-8 production partially through ATP-gated ion channel $\mathrm{P} 2 \mathrm{X}^{26}$ and adenosine receptor as a result of ATP degradation. ${ }^{30,31,45}$ Through the use of specific inhibitors, our results indicated that neither the $\mathrm{P} 2 \mathrm{X}$ receptor nor the adenosine $\mathrm{A}_{2 \mathrm{~b}}$ receptor played a significant role in mediating IL-8 production in response to HNP stimulation. Interestingly, a recent study demonstrated that the human cathelicidin-derived cationic peptide LL37, found in neutrophils, in bone marrow-derived cells, and in epithelial cells may promote IL-1 $\beta$ production in LPS-primed monocytes through the activation of $\mathrm{P} 2 \mathrm{X}_{7}$ receptors. ${ }^{46}$

We demonstrate that the mRNAs of $\mathrm{P} 2 \mathrm{Y}$ receptors $\mathrm{P}_{2} \mathrm{Y}_{4}$ and $\mathrm{P}_{2} \mathrm{Y}_{6}$, but not $\mathrm{P} 2 \mathrm{Y}_{2}$, express in lung epithelial cells. These P2Y receptors are ligands for UTP, UDP, and ATP, respectively, though $\mathrm{P}_{2} \mathrm{Y}_{4}$ also recognizes ATP. Antisense oligonucleotides were used to block expression of the P2Y receptors because of the lack of available specific inhibitors and antibodies. We found that the inhibition of $\mathrm{P}_{2} \mathrm{Y}_{6}$ receptor expression dramatically reduced HNPinduced IL- 8 production by approximately $60 \%$ and by more than $70 \%$ in A549 cells and in primary human small airway epithelial cells, respectively. These results, obtained by using $\mathrm{P}_{2} \mathrm{Y}_{6}$ receptor antisense oligonucleotides, are consistent with the fact that an almost complete attenuation of IL- 8 was achieved by using the P2Y inhibitor reactive blue, which is more specific to $\mathrm{P} 2 \mathrm{Y}_{6}$ than to $\mathrm{P} 2 \mathrm{Y}_{4}$ receptor. ${ }^{22,28}$

The exact mechanisms by which HNPs signal through the $\mathrm{P}_{2} \mathrm{Y}_{6}$ receptor remain unknown. Several possibilities are under investigation. One is that HNPs interact with the $\mathrm{P}_{2} \mathrm{Y}_{6}$ receptor through binding sites that are distinct from those for UDP binding; HNPs act at the cell surface through interaction with one or more specific ligands, which in turn activate $\mathrm{P}_{2} \mathrm{Y}_{6}$. Another is that an anchor or a coligand(s) associated with the $\mathrm{P}_{2} \mathrm{Y}_{6}$ receptor is required for $\mathrm{HNP}$ binding and action. Yet another is that HNP induces the upregulation of UDP after an unknown mechanism that activates the $\mathrm{P}_{2} \mathrm{Y}_{6}$ receptor, resulting in specific IL-8 induction. Selective induction of IL- 8 by UDP has been well documented under different in vitro conditions. ${ }^{27,28,47,48}$ Additionally, HNPs modulate the affinity of $\mathrm{P}_{2} \mathrm{Y}_{6}$ for UDP. Finally, HNPs may synergize with UDP.

The $\mathrm{P}_{2} \mathrm{Y}_{14}$ receptor has been recently cloned, and $\mathrm{P}_{2} \mathrm{Y}_{14}$ mRNA is expressed in A549 cells, the bronchial epithelial cells (BEAS-2B), and primary alveolar epithelial type 2 cells. ${ }^{24}$ It has been demonstrated that the $\mathrm{P} 2 \mathrm{Y}_{14}$ receptor specifically responds to UDP glucose but not to ATP, ADP, UTP, or UDP. ${ }^{23,49}$ Furthermore, the present study shows that the use of $\mathrm{P}_{2} \mathrm{Y}_{6}$ antisense nucleotides resulted in complete inhibition of IL-8 release induced by stimulation with HNP. Thus, we do not anticipate that $\mathrm{P} 2 \mathrm{Y}_{14}$ is significantly involved in the HNP-P2 $\mathrm{Y}_{6}$ signaling pathway.

In conclusion, we demonstrate that HNP-induced IL-8 production in epithelial cells is predominantly regulated by the 7-transmembrane, G-coupled-protein $\mathrm{P}_{2} \mathrm{Y}_{6}$ receptor. However, the binding of HNPs to the cell surface is not competitively blocked by excessive 
amounts of UDP, a specific ligand of $\mathrm{P}^{2} \mathrm{Y}_{6}$ receptor, suggesting that mechanisms other than direct interaction between HNPs and $\mathrm{P}_{2} \mathrm{Y}_{6}$ are involved. The current study provides potential therapeutic implications to modulate HNP-P2 $\mathrm{Y}_{6}$-induced excessive inflammatory responses without interrupting charge-dependent antimicrobial activity of HNPs in inflammatory conditions.

\section{References}

1. Faurschou M, Borregaard N. Neutrophil granules and secretory vesicles in inflammation. Microbes Infect. 2003;5:1317-1327.

2. Gabay JE, Almeida RP. Antibiotic peptides and serine protease homologs in human polymorphonuclear leukocytes: defensins and azurocidin. Curr Opin Immunol. 1993;5:97-102.

3. Ganz T, Lehrer RI. Defensins. Curr Opin Immunol. 1994;6:584-589.

4. Zhang XL, Selsted ME, Pardi A. NMR studies of defensin antimicrobial peptides, I: resonance assignment and secondary structure determination of rabbit NP-2 and human HNP-1. Biochemistry. 1992;31:11348-11356.

5. Pardi A, Zhang XL, Selsted ME, Skalicky JJ, Yip PF. NMR studies of defensin antimicrobial peptides, II: three-dimensional structures of rabbit NP-2 and human HNP-1. Biochemistry. 1992;31: 11357-11364.

6. Ihi T, Nakazato M, Mukae H, Matsukura S. Elevated concentrations of human neutrophil peptides in plasma, blood, and body fluids from patients with infections. Clin Infect Dis. 1997;25: 1134-1140.

7. Ashitani J, Mukae H, Ihiboshi H, et al. Defensin in plasma and in bronchoalveolar lavage fluid from patients with acute respiratory distress syndrome. Nihon Kyobu Shikkan Gakkai Zasshi. 1996;34: 1349-1353.

8. Ashitani J, Mukae H, Nakazato M, et al. Elevated concentrations of defensins in bronchoalveolar lavage fluid in diffuse panbronchiolitis. Eur Respir J. 1998;11:104-111.

9. Voglis S, Downey G, Grinstein S, Slutsky AS, Zhang $\mathrm{H}$. HNP can impair PMN phagocytic function [abstract]. Am J Respir Crit Care Med. 2002 165:A533.

10. Panyutich AV, Panyutich EA, Krapivin VA, Baturevich EA, Ganz T. Plasma defensin concentrations are elevated in patients with septicemia or bacterial meningitis. J Lab Clin Med. 1993;122: 202-207.

11. Soong LB, Ganz T, Ellison A, Caughey GH. Purification and characterization of defensins from cystic fibrosis sputum. Inflamm Res. 1997;46:98102.

12. Hiemstra PS, van Wetering S, Stolk J. Neutrophil serine proteinases and defensins in chronic obstructive pulmonary disease: effects on pulmonary epithelium. Eur Respir J. 1998;12:12001208.

13. Yang D, Chen Q, Chertov O, Oppenheim JJ. Human neutrophil defensins selectively chemoattract naive $\mathrm{T}$ and immature dendritic cells. J Leukoc Biol. 2000;68:9-14.

14. Territo MC, Ganz T, Selsted ME, Lehrer R. Monocyte-chemotactic activity of defensins from human neutrophils. J Clin Invest. 1989;84:20172020.

15. Van Wetering S, Mannesse-Lazeroms SP, van Sterkenburg MA, Hiemstra PS. Neutrophil defensins stimulate the release of cytokines by airway epithelial cells: modulation by dexamethasone. Inflamm Res. 2002;51:8-15.

16. Mahalingam S, Karupiah G. Chemokines and chemokine receptors in infectious diseases. Immunol Cell Biol. 1999;77:469-475.

17. Kanegasaki S, Nomura $\mathrm{Y}$, Nitta N, et al. A novel optical assay system for the quantitative measurement of chemotaxis. J Immunol Methods. 2003;282:1-11.
18. Durr M, Peschel A. Chemokines meet defensins: the merging concepts of chemoattractants and antimicrobial peptides in host defense. Infect Immun. 2002;70:6515-6517.

19. Cole AM, Ganz T, Liese AM, Burdick MD, Liu L Strieter RM. IFN-inducible ELR-CXC chemokines display defensin-like antimicrobial activity. J Immunol. 2001;167:623-627.

20. Hoover DM, Boulegue C, Yang D, et al. The structure of human macrophage inflammatory protein-3alpha/CCL20: linking antimicrobial and CC chemokine receptor-6-binding activities with human beta-defensins. J Biol Chem. 2002;277: 37647-37654.

21. North RA. Molecular physiology of P2X receptors. Physiol Rev. 2002;82:1013-1067.

22. von Kugelgen I, Wetter A. Molecular pharmacology of P2Y-receptors. Naunyn Schmiedebergs Arch Pharmacol. 2000;362:310-323.

23. Lee BC, Cheng T, Adams GB, et al. P2Y-like receptor, GPR105 (P2Y14), identifies and mediates chemotaxis of bone-marrow hematopoietic stem cells. Genes Dev. 2003;17:1592-1604.

24. Muller T, Bayer H, Myrtek D, et al. The P2Y14 receptor of airway epithelial cells: coupling to intracellular $\mathrm{Ca}^{2+}$ and IL-8 secretion. Am J Respir Cell Mol Biol. 2005;33:601-609.

25. Di Virgilio F, Chiozzi P, Ferrari D, et al. Nucleotide receptors: an emerging family of regulatory molecules in blood cells. Blood. 2001;97:587-600.

26. Idzko M, Panther E, Bremer HC, et al. Stimulation of $\mathrm{P} 2$ purinergic receptors induces the release of eosinophil cationic protein and interleukin-8 from human eosinophils. Br J Pharmacol. 2003;138: 1244-1250.

27. Warny M, Aboudola S, Robson SC, et al. P2Y(6) nucleotide receptor mediates monocyte interleukin-8 production in response to UDP or lipopolysaccharide. J Biol Chem. 2001;276:26051-26056.

28. Idzko M, Panther E, Sorichter S, et al. Characterization of the biological activities of uridine diphosphate in human dendritic cells: influence on chemotaxis and CXCL8 release. J Cell Physiol. 2004;201:286-293.

29. Lazarowski ER, Boucher RC, Harden TK. Constitutive release of ATP and evidence for major contribution of ecto-nucleotide pyrophosphatase and nucleoside diphosphokinase to extracellular nucleotide concentrations. J Biol Chem. 2000;275: 31061-31068.

30. Burvall K, Palmberg L, Larsson K. Effects by 8-bromo-cyclicAMP on basal and organic dustinduced release of interleukin- 6 and interleukin- 8 in A549 human airway epithelial cells. Respir Med. 2003;97:46-50.

31. Meade CJ, Worrall L, Hayes D, Protin U. Induction of interleukin 8 release from the HMC-1 mast cell line: synergy between stem cell factor and activators of the adenosine $\mathrm{A}(2 \mathrm{~b})$ receptor. Biochem Pharmacol. 2002;64:317-325.

32. Porro JA, Lee J-H, de Azavedo J, et al. Direct and indirect bacterial killing functions of neutrophil defensins in lung explants. Am J Physiol Lung Cell Mol Physiol. 2001;281:L1240-L1247.

33. Zhang H, Porro G, Orzech N, Mullen B, Liu M, Slutsky AS. Neutrophil defensins mediate acute inflammatory response and lung dysfunction in dose-related fashion. Am J Physiol Lung Cell Mol Physiol. 2001;280:L947-L954.

34. Lee JH, Del Sorbo L, Uhlig S, et al. Intercellular adhesion molecule-1 mediates cellular cross-talk between parenchymal and immune cells after lipopolysaccharide neutralization. J Immunol. 2004;172:608-616.

35. Zhao DM, Xue HH, Chida K, et al. Effect of erythromycin on ATP-induced intracellular calcium response in A549 cells. Am J Physiol Lung Cell Mol Physiol. 2000;278:L726-L736.

36. Chertov $\mathrm{O}$, Michiel DF, Xu L, et al. Identification of defensin-1, defensin-2, and CAP37/azurocidin as T-cell chemoattractant proteins released from interleukin-8-stimulated neutrophils. J Biol Chem. 1996;271:2935-2940.

37. Lillard JW Jr, Boyaka PN, Chertov O, Oppenheim JJ, McGhee JR. Mechanisms for induction of acquired host immunity by neutrophil peptide defensins. Proc Natl Acad Sci U S A. 1999;96:651656.

38. Ishii H, Fujii T, Hogg JC, et al. Contribution of IL-1 beta and TNF-alpha to the initiation of the peripheral lung response to atmospheric particulates (PM10). Am J Physiol Lung Cell Mol Physiol. 2004;287:L176-L183.

39. Sparkes RS, Kronenberg M, Heinzmann C, et al Assignment of defensin gene(s) to human chromosome 8p23. Genomics. 1989;5:240-244.

40. Linzmeier R, Michaelson D, Liu L, Ganz T. The structure of neutrophil defensin genes. FEBS Lett. 1993;321:267-273.

41. Aarbiou J, Rabe KF, Hiemstra PS. Role of defensins in inflammatory lung disease. Ann Med. 2002;34:96-101.

42. Van Wetering S, Mannesse-Lazeroms SP, Van Sterkenburg MA, Daha MR, Dijkman JH, Hiemstra PS. Effect of defensins on interleukin-8 synthesis in airway epithelial cells. Am J Physiol. 1997;272:L888-L896.

43. Sakamoto N, Mukae H, Fujii T, et al. Differential effects of $\alpha$ - and $\beta$-defensin on cytokine production by cultured human bronchial epithelial cells. Am J Physiol Lung Cell Mol Physiol. 2005;288: L508-L513.

44. Chaly YV, Paleolog EM, Kolesnikova TS, Tikhonov II, Petratchenko EV, Voitenok NN. Neutrophil alpha-defensin human neutrophil peptide modulates cytokine production in human monocytes and adhesion molecule expression in endothelial cells. Eur Cytokine Netw. 2000;11:257-266.

45. Crane JK, Olson RA, Jones HM, Duffey ME. Release of ATP during host cell killing by enteropathogenic $E$. coli and its role as a secretory mediator. Am J Physiol Gastrointest Liver Physiol. 2002;283:G74-G86.

46. Elssner A, Duncan M, Gavrilin M, Wewers MD. A novel P2X7 receptor activator, the human cathelicidin-derived peptide LL37, induces IL-1 beta processing and release. J Immunol. 2004;172:4987-4994.

47. Kim SG, Soltysiak KA, Gao ZG, Chang TS, Chung E, Jacobson KA. Tumor necrosis factor alpha-induced apoptosis in astrocytes is prevented by the activation of $\mathrm{P}_{2} \mathrm{Y}_{6}$, but not $\mathrm{P}_{2} \mathrm{Y}_{4}$ nucleotide receptors. Biochem Pharmacol. 2003;65:923-931.

48. Kim SG, Gao ZG, Soltysiak KA, Chang TS, Brodie $\mathrm{C}$, Jacobson $\mathrm{KA}$. $\mathrm{P} 2 \mathrm{Y}_{6}$ nucleotide receptor activates PKC to protect $1321 \mathrm{~N} 1$ astrocytoma cells against tumor necrosis factor-induced apoptosis. Cell Mol Neurobiol. 2003;23:401-418.

49. Skelton L, Cooper M, Murphy M, Platt A. Human immature monocyte-derived dendritic cells express the $\mathrm{G}$ protein-coupled receptor GPR105 (KIAA0001, P2Y 14 ) and increase intracellular calcium in response to its agonist, uridine diphosphoglucose. J Immunol. 2003;171: 1941-1949. 